\title{
Действие двухвалентных катионов металлов на функционирование пероксисомальной малатдегидрогеназы из листьев кукурузы
}

\author{
Гатауллина М.О., Епринцев А.Т. \\ ФГБОУ ВО «Воронежский государственный университет», Воронеж
}

Поступила в редакцию 26.01.2018 г.

\begin{abstract}
Модифицированная многостадийная очистка, включающая в себя изоплотностное центрифугирование с помощью ступенчатого градиента сахарозы при концентрации от 1,3 до 2,5 М. Разделение субклеточных фракций осуществляли путем ультрацентрифугирования при 100000 g. Определяющее значение для эффективной очистки фермента имела ионообменная хроматография, которая позволила получить гомогенные препараты малатдегидрогеназы из мезофилла листьев кукурузы. Степень очистки фермента, обладающего удельной активностью 513 Е/мг белка, составила 135 раза, а выход - 4\%. На полученном препарате было исследовано влияние двухвалентных катионов, таких как кальций, барий, магний и марганец. Графоаналитическим методом были определены тип и характер регулирующего действия исследуемых катионов на малатдегидрогеназную систему. Показано, что ионы магния в малых дозах (до $2 \mathrm{mM}$ ) оказывают активирующее действие на работу энзима, а в больших (более 2 мM) - ингибируют активность малатдегидрогеназы. Другие исследованные катионы оказывали ингибирующее действие на функционирование фермента.
\end{abstract}

Ключевые слова: малатдегидрогеназа, Zea mays, мезофилл, ионообменная хроматография, электрофорез, изоплотностное центрифугирование.

\section{The effect of divalent metal cations on the functioning of peroxisomal malate dehydrogenase from maize leaves}

\author{
Gataullina M.O., Eprintsev A.T. \\ Voronezh State University, Voronezh
}

\begin{abstract}
The enzymes of the Krebs cycle in the plant cell are usually represented by several isoforms localized in the mitochondrial, peroxisomal and other plant cell fractions. The physiological role of isoenzymes of malate dehydrogenase is now well studied for the mitochondrial form of this enzyme. The aim of this work was to study the effect of divalent metal ions on the activity of peroxisomal MDH in the mesophyll of maize. Modified multistage purification of the peroxisomal isoform malate dehydrogenase (E.C. 1.1.1.37) from the maize maize mesophyll, including isotopic centrifugation with a step gradient of sucrose at a concentration of 1.3 to $2.5 \mathrm{M}$. The separation of subcellular fractions (peroxisomes, mitochondria and cytosol) was performed by ultracentrifugation at $100,000 \mathrm{~g}$. The determining value for effective purification of the enzyme was ion-exchange chromatography, which made it possible to obtain homogeneous preparations of malate dehydrogenase from the maize mesophyll of maize leaves. The degree of purification of the enzyme, which has a specific activity of $513 \mathrm{U} / \mathrm{mg}$ protein, was 135 times, and the yield was $4 \%$. The use of ionexchange chromatography with the use of DEAE-Sephacel for ion-detection in the quality opens up prospects for its use for fine separation of molecular isoforms of oxidative enzymes close to tricarboxylic acid cycles.

The preparation of the peroxisomal form of the enzyme preparations studied in the electrophoretically homogeneous state made it possible to conduct a comprehensive study of the regulatory aspects of the functioning of MDH. On the obtained preparation, the influence of divalent cations such as calcium, barium, magnesium and manganese was investigated. The type and nature of the regulating effect of the cations under study on the malate dehydrogenase system were determined by the graphoanalytical method. It is shown that
\end{abstract}


magnesium ions in small doses (up to $2 \mathrm{mM}$ ) exert an activating effect on the enzyme activity, and in large (more than $2 \mathrm{mM}$ ) - inhibit the activity of malate dehydrogenase. Other cations studied had an inhibitory effect on the functioning of the enzyme.

Thus, an analysis of the data obtained indicates that the divalent cations studied can participate in the regulation of the catalytic action of the malate dehydrogenase enzyme system in the mesophyll of Zea mays leaves.

Keywords: malate dehydrogenase, Zea mays, mesophyll, ion exchange chromatography, electrophoresis, isotopic centrifugation.

\section{Введение}

Малатдегидрогеназа (МДГ, НАД-зависимая оксидоредуктаза, КФ 1.1.1.37) фермент, имеющий множество изоформи участвующий во взаимопревращении оксалоацетата в малат [1].

В листьях кукурузы изоферменты МДГ локализованы в цитоплазме, митохондриях и пероксисомах и различаются между собой по свойствам и функциям [2]. Особый интерес вызывает изучение функционирования системы МДГ в пероксисомaх, в которых на определенных этапах онтогенеза появляются ферменты глиоксилатного цикла, участвующие в реутилизации мембранных липидов и белков отмирающих клеток. Кроме того, МДГ участвует в транспорте аминокислот в процессе адаптивной реакции клеточного метаболизма на стрессовые условия [3,4].

К таким возможным стрессам относится излишнее удобрение почв микроэлементами и их загрязнение тяжелыми металлами[5]. Их ионы могут осуществлять регуляцию активности ферментов путем их взаимодействия с активным центром фермента. При этом одни ионы, например магний, активируют работу МДГ, выделенную из разных объектов, другие же (цинк, медь, кобальт) ингибируют активность этой ферментной системы [6,7].

\section{Эксперимент}

Объектом исследования являлись 10-ти дневные проростки кукурузы (ZeamaysL., сорта Воронежская 76), выращенные гидропонным методом при $25^{\circ} \mathrm{C}$. Для выделения мезофильной ткани использовали метод Клечковского [8].

Активность МДГ определяли по изменению оптической плотности реакционной смеси, определяемой скоростью образования или расходования НАДН, спектрофотометрически при 340 нм на СФ-2000 («Ломо», Россия). Среда при определении скорости восстановления оксалоацетата содержала 100 мМтрис-HCl буфер, pH 8.0, 1.5 мМ оксалоацетат; 0.15 мМ НАДН. Активность МДГ в прямой реакции определяли в реакционной среде, содержавшей 100 мМ Трис-НCl буфер, $\mathrm{pH} 8.0,4$ мМ малата и 1 мМ НАД ${ }^{+}$. За единицу ферментативной активности МДГ принимали количество фермента, которое превращало (для обратной реакции) или образовывало (для прямой реакции) 1 мкмоль НАДН за 1 мин при $25^{\circ} \mathrm{C}$.

Для получения пероксисомальной фракции гомогенат дважды центрифугировали в течение 3-4 мин при 1000 g. Затем супернатант центрифугировали при 14000 g в течение 20 мин на центрифуге Eppendorf 5804 R (Германия). Осадок, содержащий пероксисомы, подвергали изоплотностному центрифугированию в ступенчатом градиенте $(1.3,1.5,1.8,2.3$ и $2.5 \mathrm{M})$ сахарозы после нанесения на его вершину. Органеллы разделялись в результате центрифугирования на центрифуге («Backman», США)в течение 90 мин при $100000 \mathrm{~g}$ и $0-+4^{\circ}$ С.Интактныепероксисомы обнаруживали на границе ступеней градиента сахарозы 2.3 и $2.5 \mathrm{M}$. Пероксисомы разрушалиосмотическим шоком в 50 мМтрис- $\mathrm{HCl}$ буфере, $\mathrm{pH}$ 8.0. Низкомолекулярные примеси 
отделяли на колонке (1.5x20 см) с сефадексомG-25 («Pharmacia», Швеция). Фракцию, содержащую фермент, подвергали ионообменной хроматографии на колонке (1.5 x 12 см) с ДЭАЭ-Sephacel («GEHealthcare», Швеция). Элюцию проводили линейным градиентом $\mathrm{NaCl}$ (0-100 мМ), собирая фракции с активностью МДГ. Электрофорез в 7\%-ном полиакриламидном геле (ПААГ) проводили пометоду Дэвиса. Гель окрашивали нитратом серебра [9].

Специфическое проявление МДГ осуществляли тетразолиевым методом. Для этого гель инкубировали в темноте при $37^{\circ} \mathrm{C}$ в среде, содержавшей 100 мМтрис-HClбуфер, $\mathrm{pH}$ 8.0, 2 М раствор малата натрия, 18 мг НАД+, 10 мг нитросинего тетразолия (предварительно растворенного в $0.5 \mathrm{~cm}^{3}$ этиленгликоля) и 0.6 мг феназинметасульфата. Содержание белка определяли по методу Лоури [10].

\section{Обсуждение результатов}

Малатдегидрогеназная система представлена большим количеством изоферментов, локализованных в различных компартментах клетки. Изоплотностное центрифугирование позволило выявить, что для глиоксисомальной фракции характерно наличие только одной изоформы, которая в дальнейшем подвергалась очистке[11].

После четырехстадийной очистки была получена пероксисомальная МДГ, удельная активность которой составила 513 Е/мг белка, степень очистки - 135 и выход - 4\%. Известно большое количество хроматографических методов, позволяющих эффективно очистить вещества, различной природы. [12,13] Для получения высокоочищенной пероксисомальной МДГ использовали ионообменную хроматографию на ДЭАЭ-Sephacel. Максимальное количество фермента десорбировалось при элюции 35 мM NaCl (Табл.).

Таблица. Этапы очистки НАД+-зависимой пероксисомальноймалатдегидрогеназы из мезофилла кукурузы $(\mathrm{n}=3, \mathrm{p} \leq 0.05)$

\begin{tabular}{|c|c|c|c|c|c|c|}
\hline Стадия & $\begin{array}{c}\mathrm{V}, \text { cм}^{3} \\
\text { Белок, } \\
\text { мг }\end{array}$ & $\begin{array}{c}\text { Общая актив- } \\
\text { ность, Е. }\end{array}$ & $\begin{array}{c}\text { Удельная ак- } \\
\text { тивность, Е/мг } \\
\text { белка }\end{array}$ & $\begin{array}{c}\text { Выход, } \\
\%\end{array}$ & $\begin{array}{c}\text { Степень } \\
\text { очистки }\end{array}$ \\
\hline Гомогенат & 10 & 93.64 & 357 & 3.8 & 100 & 1 \\
\hline $\begin{array}{c}\text { Изоплотностное центрифу- } \\
\text { гирование }\end{array}$ & 1 & 14.3 & 73 & 5.1 & 20 & 1.3 \\
\hline $\begin{array}{c}\text { Гель-фильтрация на сефа- } \\
\text { дексе G-25 }\end{array}$ & 6 & 6.44 & 56 & 8.7 & 16 & 2.3 \\
\hline $\begin{array}{c}\text { Ионообменная хромато- } \\
\text { графия на ДЭАЭ- } \\
\text { SЕРНАСЕL }\end{array}$ & 3 & 0.03 & 15,4 & 513 & 4 & 135 \\
\hline
\end{tabular}

При универсальном окрашивании нитратом серебра и специфическом окрашивании тетразолиевым методом полиакриламидного геля, полученного после электрофореза очищенной МДГ, была обнаружена только одна белковая полоса с $\mathrm{Rf}=0.48$. Это свидетельствует о гомогенности очищенного препарата малатдегидрогеназы (рис. 1).

Ионы металлов играют важную роль в метаболизме всех живых организмов. Одни катионы являются для энзимов необходимыми коферментами, без которых невозможно протекание реакции[14,15]. Другие, в том числе тяжелые металлы, загрязнение которыми вызывает определенные опасения, ингибируют эти процессы[16$18]$. 
Было исследовано влияние хлоридов ионов $\mathrm{Mg}^{2+}, \mathrm{Mn}^{2+}, \mathrm{Ba}^{2+}, \mathrm{Ca}^{2+}$ на активность очищенного препарата. Показано, что данные катионы ингибируют работу МДГ в любых концентрациях, за исключением небольших (до 2 мМ) концентраций $\mathrm{MgCl}_{2}$ (рис.2). Анализ полученных данных, осуществленный с помощью графиков Лайнуивера-Берка, позволил установить наличие разных типов ингибирования. Конкурентный тип ингибирования характерен для действия катионов марганца, магния и кальция (рис.3,4,5).

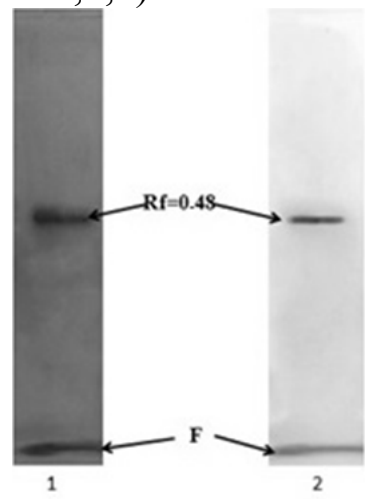

Рис.1. ПААГ после электрофореза при рН 9 изоформы пероксисомальной МДГ, окрашенные нитратом серебра (1) и специфиче-

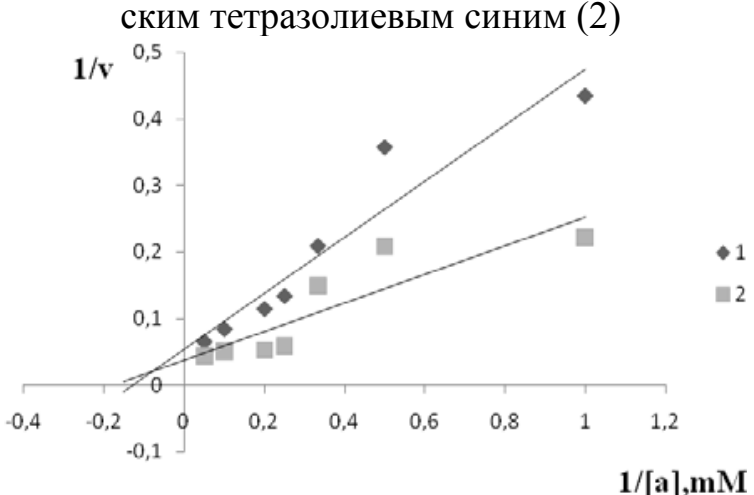

Рис.3. Ингибирование ионами марганца. Концентрация оксалоацетата составляла (1) $-0.1 \mathrm{MM} ; 2-0.2 \mathrm{MM}$

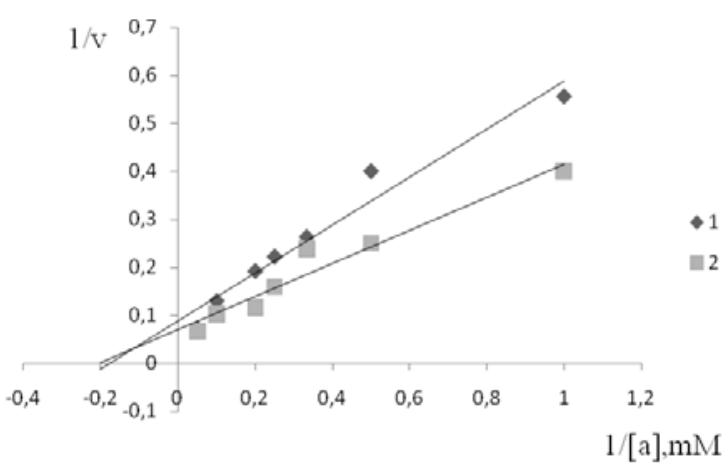

Рис.5. Ингибирование ионами кальция.

Концентрация оксалоацетата составляла (1) $0.1 \mathrm{MM} ; 2-0.2 \mathrm{MM}$

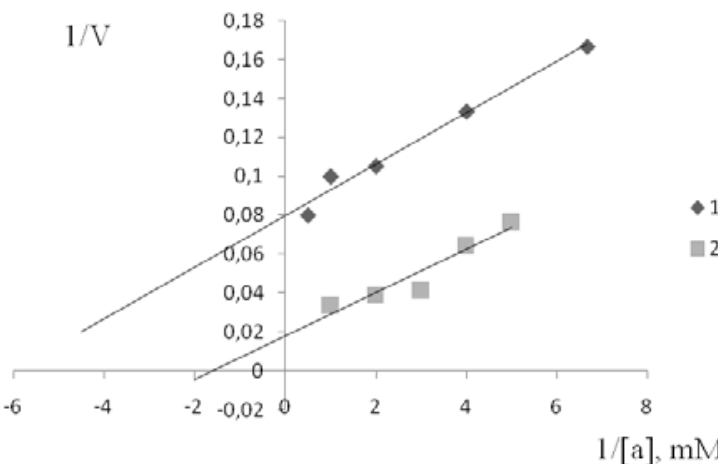

Рис.2. Активация МДГ ионами магния в концентрации до 2 мМ. Концентрация оксалоацетата составляла (1) - $0.1 \mathrm{MM}$;

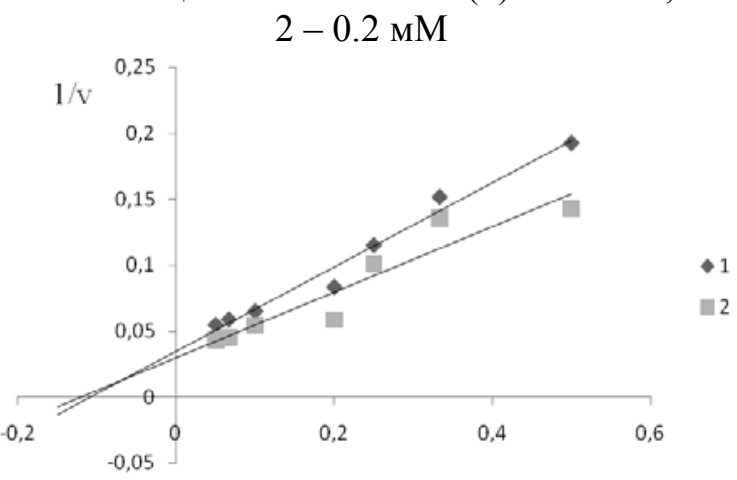

$1 /[\mathrm{a}], \mathrm{mM}$

. Рис. 4. Ингибирование ионами магния в концентрации более $2 \mathrm{MM}$. Концентрация оксалоацетата составляла (1) $-0.1 \mathrm{мM}$;

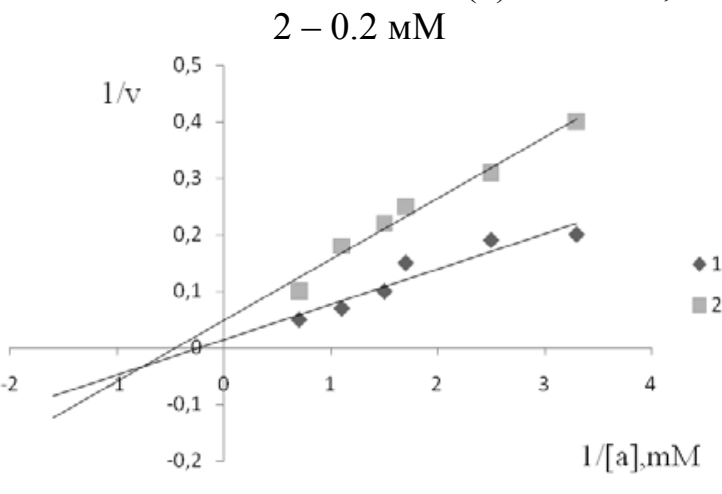

Рис.6.Ингибирование ионами бария.

Концентрация оксалоацетата составляла (1) $-0.1 \mathrm{MM} ; 2-0.2 \mathrm{MM}$

Этот тип торможения работы фермента свидетельствует о важной роли катионов в работе активного центра малатдегидрогеназы [19]. Повышение концентра- 
ции субстрата, как правило, обеспечивает снижение тормозящего действия ингибитора. Для катионов бария выявлен неконкурентный тип торможения этими катионами работы пероксисомальной малатдегидрогеназы (рис.6). Для неконкурентного типа характерно отсутствие эффекта ослабления действия субстрата на ингибирующий фактор. Подобный тип ингибирования показывает, что исследуемые катионы связываются на участке белковой молекулы фермента, отличающемся от активного центра, причем связь осуществляется, как с энзимом, так и фермент-субстратным комплексом. Можно предположить, что модификация молекулы фермента осуществляется путем взаимодействия данных катионов с цистеином, что приводит к изменению функциональной активности малатдегидрогеназы [20].

\section{Заключение}

Выделение с помощью изоплотностного центрифугирования в градиенте плотности сахарозы и очистка методом ионообменной хроматографии на ДЭАЭSephacel позволили получить высокоочищенные препараты пероксисомальной малатдегидрогеназы из мезофилла листьев кукурузы. Исследование влияния катионов различных металлов позволило выявить их ингибирующее действие на функционирование малатдегидрогеназы. Установлен различный механизм торможения активности пероксисомальной МДГ. При этом выявлено конкурентное ингибирование для катионов марганца, магния и кальция и неконкурентное торможение для ионов бария.

Работа выполнена при финансовой поддержке Российского Научного Фонда (грант РНФ№14-14-00721)

\section{Список литературы}

1. Землянухин А.А., Землянухин Л.А. Большой практикум по физиологии и биохимии растении. Воронеж: Изд-во Воронеж. ун-та. 1996. 185 с.

2. Епринцев А.Т., Фалалеева М.И., Лященко М.С., Гатауллина М.О. и др. // Прикл. биохимия и микробиология. 2016. Т. 52. № 2. C. 168-173.

3. Епринцев А.Т., Попов В.Н., Шевченко М.Ю. Экспрессия и регуляция ферментов глиоксилатного цикла Воронеж. Центрально-Черноземное книжное издательство. 2005. 224 с.

4. Сатар А.Ф., Парфенова И.В., Мальцева Е.В., Фалалеева М.И. и др. // Сорбиионные и хроматографические прочессы. 2010. Т. 10. № 2 C. 231-236

5. Минкина Т.М., Бурачевская М.В., Чаплыгин В.А., Бакоев С.Ю. и др. // Научный журнал Российского НИИ проблем мелиоращии. 2011. № 4. С. 9-10.

6. Vesna Hadži-Tašković Šukalovića, Mirjana Vuletićb, Ksenija Markovićb, Željko Vučinića// Plant Science. 2011. Vol. 181. Issue 4.pp 465-470.
7. Бездудная Е.Ф., Калиман П.А. // Укр. біохім. журн., 2008, т. 80, № 1 стр. 83 - 88

8. Епринцев А. Т., Федорина О. С. // Функционирование малатдегидрогеназной системы в мезофилле и обкладке листьев кукурузы в условиях солевого стресса. Физиология растений. 2007. Т. 54. №. 6. С. 820-827.

9. Davis B.J., Ornstein L. // Society for the study at the New York Academy of medicine. 1959. pp. 112-118.

10. Lowry O.H. Rosebrough H.J., Papp A.H. // J. Biologi. 1951. Vol. 193. pp. 265-275.

11. Епринцев А.Т., Гатауллина М.О., Лященко М.С. // Прикл. биохимия $и$ микробиология. 2016. Т. 52. №4 С.137-144

12. Карпов С.И., Roessner F., Селеменев В.Ф. , Гульбин С.С. , Беланова Н.А. и др. // Сорбиионные и хроматографические проиессы. 2013. Т. 13. № 2. С. 125-140.

13. Селеменев В.Ф., Рудаков О.Б., Славинская Г.В., Дроздова Н.В. Пигменты пищевых производств (меланоиды). М. Де Ли ПРИНТ. 2000. 246 с. 
14. Родионова Л. В. Физиологическая роль макрои микроэлементов (обзор литературы) //Бюллетень Восточно-Сибирского научного центра Сибирского отделения Российской академии медицинских наук. 2005. №. 6. С. 195-199.

15. Огурцов А. Н. Кинетика ферментативных реакций. Харьков:НТН «ХПИ».2007. 146 c.

16. Баяндина И. И., Загурская Ю. В. // Сиб. мед. журин. 2014. № 8. С.107-111.

\section{References}

1. Zemljanuhin A. A., Zemljanuhin L. A. Bol'shoj praktikum po fiziologii $\mathrm{i}$ biohimii rastenii. Voronezh: Izd-vo Voronezh. un-ta, 1996, pp. 185.

2. Eprincev A.T., Falaleeva M.I., Ljashhenko M.S., Gataullina M.O. et al., Prikl. biohimija $i$ mikrobiologija, 2016, Vol. 52, No 2, pp. 168173.

3. Eprincev A.T., Popov V.N., Shevchenko M.Ju. Jekspressija i reguljacija fermentov glioksilatnogo cikla, Voronezh, Central'noChernozemnoe knizhnoe izdatel'stvo, 2005, pp. 224.

4. Satar A.F., Parfenova I.V., Mal'ceva E.V., Falaleeva M.I. et al., Sorbtsionnye $i$ khromatograficheskie protsessy, 2010, Vol. 10, No 2, ppr. 231-236.

5. Minkina T.M., Burachevskaja M.V., Chaplygin V.A., Bakoev S.Ju. et al., Nauchnyj zhurnal Rossijskogo NII problem melioracii, 2011, No 4, pp. 9-10.

6. Vesna Hadži-Tašković Šukalovića, Mirjana Vuletićb, Ksenija Markovićb, Željko Vučinića, Plant Science, 2011, Vol. 181, Issue 4, pp. 465470.

7. Bezdudnaja E.F., Kaliman P.A., $U k r$. biohim. zhurn., 2008, Vol. 80, No 1, pp. 83-88.

8. Eprincev A.T., Fedorina O.S., Funkcionirovanie malatdegidrogenaznoj sistemy $v$ mezofille i obkladke list'ev kukuruzy $v$ uslovijah solevogo stressa. Fiziologija rastenij, 2007, Vol. 54, No. 6, pp. 820-827.

9. Davis B.J., Ornstein L.,/ Society for the study at the New York Academy of medicine, 1959, pp. 112-118.

Гатауллина Марина Олеговна - аспирант Воронежского госуниверситета, Воронеж
17. Серегин И. В., Кожевникова А. Д. //Физиология растений. 2006. Т. 53. №. 2. С. 285-308.

18. Титов А.Ф., Казнина Н.М., Таланова В.В. Тяжелье металль и растения : монография / Институт биологии КарНЦ РАН. Петрозаводск : Карельский научный центр РАН. 2014. 194 с.

19. Ленинджер А. Основы биохимии. Изво Мир. 1985. Т.2. 369 с.

20. Парфенова И.В. автореф. дис. канд. биолог. наук. Воронеж. 2011. 23 с.

10.Lowry O.H. Rosebrough H.J., Papp A.H., Protein meacuament with the folin pihend reagent. J. Biologi., 1951, Vol. 193, pp. 265275.

11.Eprintsev A.T., Gataullina M.O., Ljashhenko M.S., Prikl. biohimija $i$ mikrobiologija, 2016, Vol. 52, No 4, pp.137144.

12.Karpov S.I., Roessner F., Selemenev V.F., Gul'bin S.S. et al., Sorbtsionnye i khromatograficheskie protsessy, 2013, Vol. 13, No 2, pp. 125-140.

13. Selemenev V. F., Rudakov O.B., Slavinskaya G.V., Drozdova N.V. Pigmenty prishchevyh proizvodstv (melanoidy), M., De Li PRINT, 2000, $246 \mathrm{p}$.

14.Rodionova L.V., Bjulleten' VostochnoSibirskogo nauchnogo centra Sibirskogo otdelenija Rossijskoj akademii medicinskih nauk, 2005, No 6, pp. 195-199.

15. Ogurcov A.N. Kinetika fermentativnyh reakcij, Har'kov:NTN «HPI», 2007, 146 p.

16.Bajandina I.I., Zagurskaja Ju.V., Sib. med. zhurn., 2014, No 8, pp. 107-111.

17.Seregin I.V., Kozhevnikova A.D., Fiziologija rastenij, 2006, Vol. 53, No 2, pp. 285-308.

18.Titov A.F., Kaznina N.M., Talanova V.V. Tjazhelye metally i rastenija : monografija / Institut biologii KarNC RAN, Petrozavodsk : Karel'skij nauchnyj centr RAN, 2014. 194 p.

19.Lenindzher A. Osnovy biohimii. Iz-vo Mir, 1985,Vol .2, pp. 369.

20.Parfenova I.V. avtoref. dis. kand. biolog. nauk. Voronezh, 2011, 23 p.

Gataullina Marina Olegovna- $\mathrm{PhD}$ student in Voronezh State Univercity, Voronezh 
Епринцев Александр Трофимович - д.б.н., проф., кафедра биохимии и физиологии клетки, Воронежский государственный университет, Воронежтел.(473)2208877
Eprintsev Alexander Trofimovich - Doctor of Biology, Department of Biochemistry and Physiology, Voronezh State University, Voronezh, E-mail: bc366@bio.vsu.ru, 